\title{
Selection of starter culture for production of indigenous fermented milk product (Misti dahi)
}

\author{
J Ghosh, GS Rajorhia
}

Dairy Technology Division, National Dairy Research Institute, Karnal, 132001, India

(Received 29 August 1988; accepted 5 December 1989)

\begin{abstract}
Summary - Misti dahi is a traditional Indian fermented milk product prepared from partially concentrated sweetened milk. Besides variations in chemical and microbiological qualities the market survey of Misti dahi has revealed many flavour defects such as fruity, alcoholic, acidic or flat taste and textural defects such as gassiness, weak body, wheying-off and dried surface. Since this product is gaining commercial significance, the technology for its industrial production has been developed. Eight lactic cultures, viz $S$ lactis $\left(C_{10}\right)$, $S$ diacetylactis $\left(D_{R} C_{1}\right) ; S$ cremoris $\left(C_{1}\right)$; $S$ thermophilus (HST); L bulgaricus (LBW); $1: 1$ mixture of $\mathrm{C}_{10}$ and $\mathrm{DRC}_{1} ; 1: 1$ mixture of HST and LBW; LF-40 (a mixed culture of different strains of $S$ lactis, $S$ diacetylactis, $S$ cremoris and Leuconostoc) were examined for their ability to grow in a concentrated, sweetened milk system (18\% milk solids and $14 \%$ sucrose). On the basis of lactic acid, diacetyl and acetyl methyl carbinol production and $\mathrm{pH}$ and curd tension measurements, the LF-40 culture was found to be the most suitable for commercial production of Misti dahi.
\end{abstract}

starter culture / Misti dahi / sweetened fermented milk

Résumé - Sélection de levain pour la production d'un produit laitier fermenté indien (Misti Dahi). Le Misti dahi est un produit laitier fermenté traditionnel indien préparé à partir de lait sucré partiellement concentré. Un aperçu du marché du Misti Dahi, révèle, outre des variations dans la qualité chimique et microbiologique, plusieurs défauts de flaveur (fruitée, alcoolisée, acide, fade) et de texture (gazeuse, fragile, exsudante, à la surface desséchée). L'importance commerciale que prend ce produit a nécessité le développement d'une technologie adaptée à une production industrielle. Huit cultures lactiques : $S$ lactis $\left(C_{10}\right), S$ diacetylactis $\left(D R C_{1}\right), S$ cremoris $\left(C_{1}\right), S$ thermophilus (HST), L bulgaricus (LBW), mélange $1: 1 C_{10}$ et DRC $C_{1}$, mélange 1:1 HST et $L B W$, culture mixte de plusieurs espèces de $S$ lactis, $S$ diacetylactis, $S$ cremoris et Leuconostoc ( $L F-40$ ), ont été examinées pour leur capacité à croître dans un lait concentré sucré $(18 \%$ de matière sèche et $14 \%$ de sucrose). Sur la base de la production d'acide lactique, de diacétyle et d'acétyle méthyle carbinol, des valeurs de $\mathrm{pH}$ et de fermeté du gel obtenues, la culture LF-40 s'est avérée être la plus apte à la production industrielle de Misti Dahi.

levain / Misti Dahi / lait sucré fermenté

\section{INTRODUCTION}

Misti dahi (syn sweetened curd, lal dahi, payodhi) is a sweetened fermented milk product from the eastern part of India. It is prepared on cottage scale to cater to local demand. Traditionally, milk with cane sugar is heated in an open pan at simmering temperature $\left(60-70^{\circ} \mathrm{C}\right)$ for $6-7 \mathrm{~h}$ to evaporate part of the moisture and to develop a marked cooked flavor, slightly brown color, viscosity and other physico-chemical 
changes. After cooling to $\approx 30^{\circ} \mathrm{C}$, the mix is inoculated with commercial starter culture kept from the previous day, and transferred to earthenware pots; curdling takes place at room temperature overnight. The confectioners who sell this product do not adopt preventive measures for maintaining the reliability and purity of culture. Wide variations in total solids content (27-43 $\%)$, non fat milk solids (11-16\%) and sucrose $(13-19 \%)$ in the market samples of Misti dahi sold in Calcutta have been reported by Ghosh and Rajorhia (1987). Flavour defects such as fruity, alcoholic, highly acidic, flat taste and textural defects such as gassiness, weak body, wheyingoff and thick crust on top were observed in most of the market samples. In view of the increasing nationwide demand for Misti dahi and the growing interest on the part of the organized dairies for large-scale manufacture, there is an urgent need for modernizing the technology for its commercial production. In this communication, investigation related to selection of a suitable starter culture capable of growing in partially concentrated milk especially in the presence of sucrose are reported. The physico-chemical and sensory properties of Misti dahi as influenced by the starter culture are also described.

\section{MATERIALS AND METHODS}

\section{Milk}

Fresh raw milk was procured from a buffalo herd maintained at the National Dairy Research Institute, Karnal, India.

\section{Starter cultures}

The pure cultures of Streptococcus lactis $\left(\mathrm{C}_{10}\right)$, Streptococcus diacetylactis (DRC $)_{1}$ ), Streptococcus cremoris $\left(\mathrm{C}_{1}\right)$, Streptococcus thermophilus
(HST), Lactobacillus bulgaricus (LBW) and LF40 (a patented culture of mixture of different strains of $S$ lactis, $S$ diacetylactis, $S$ cremoris and Leuconostoc) were obtained from the Centre for National Collection of Dairy Microorganisms of the Institute and aseptically activated in the laboratory. Active cultures of $\mathrm{C}_{10}$ and DRC were mixed in equal proportions before propagation. Likewise, a 1:1 mixture of HST and LBW was also prepared.

\section{Preparation of Misti dahi}

Fresh buffalo milk was standardized to $3.5 \%$ fat and $9.0 \%$ SNF (solid non fat), heated to $65^{\circ} \mathrm{C}$ (with no hold) in a plate heat exchanger and homogenized at $56 \mathrm{~kg} / \mathrm{cm}^{2}$ (one stage). Milk was concentrated 1.44 -fold in a presterilized single effect evaporator with a vacuum of 63.5-66.4 $\mathrm{cm}$ mercury. To this concentrate, dry cane sugar was added at the rate of $14.0 \%$. The resultant mix was heated in a closed stainless steel container at $85^{\circ} \mathrm{C}$ for $10 \mathrm{~min}$ to generate a cooked flavour and slight brown colour. The mix was water-cooled to $42{ }^{\circ} \mathrm{C}$ (for thermophilic cultures) and $30^{\circ} \mathrm{C}$ (for mesophilic cultures) before inoculation with experimental cultures. The inoculated mix was aseptically distributed into presterilized polystyrene containers $(100 \mathrm{ml})$ and transferred to incubation chambers at $30{ }^{\circ} \mathrm{C}$ for $7 \mathrm{~h}$ for mixes containing the cultures of $\mathrm{C}_{10}, \mathrm{C}_{1}, \mathrm{DRC1}$, LF40 and $1: 1$ mixture of $C_{10}$ and $D R C_{1}$, while those mixes containing cultures of HST, LBW and mixtures of HST and LBW were incubated at $42{ }^{\circ} \mathrm{C}$ for $4 \mathrm{~h}$. After incubation, the samples were shifted to cold store and maintained at $4^{\circ} \mathrm{C}$.

\section{Titratable acidity (TA)}

The method described in Indian standard (1981) part XI was used for TA determination. About $10 \mathrm{~g}$ of sample was weighed and mixed with 10 $\mathrm{ml}$ of $\mathrm{CO}_{2}$-free distilled water. The contents were titrated with $0.1 \mathrm{~N}$ sodium hydroxide solution in the presence of $0.5 \%(\mathrm{w} / \mathrm{v})$ phenolpthalein indicator. TA was calculated as the percentage of lactic acid in the product. TA in the range of $0.8-0.85 \%$ was considered optimum in Misti dahi. 


\section{pH}

A digital pH meter, model L1-122 (Elico Pvt Ltd, India) was calibrated with standard buffer solution at $30^{\circ} \mathrm{C}$. Samples at $30^{\circ} \mathrm{C}$ were rendered into homogenous paste with pastle and mortar and tested for $\mathrm{pH}$ by direct immersion of electrode in the sample.

\section{Curd tension}

Curd tension was measured by the method of Chandrashekhara et al (1957) with a slight modification, as suggested by Patel and Chakraborty (1985). A 50-ml portion of mix was placed in a $100-\mathrm{ml}$ glass beaker $(7 \times 4.5 \mathrm{~cm})$ and a Hshaped blade placed in it. Mixes were than inoculated with the experimental cultures. Mixes containing $\mathrm{C}_{1}, \mathrm{C}_{10}, \mathrm{DRC}_{1}, \mathrm{LF}-40$ and a mixture of $\mathrm{C}_{10}$ and $\mathrm{DRC}_{1}$ were incubated at $30^{\circ} \mathrm{C}$ for $7 \mathrm{~h}$, while other mixes containing cultures of HST, LBW and a mixture of HST and LBW were incubated at $42{ }^{\circ} \mathrm{C}$ for $4 \mathrm{~h}$. At the end of the incubation period, the weight (in $\mathrm{g}$ ) required to pull the knife out of the curd was recorded.

\section{Diacetyl and acetyl methyl carbinol (AMC)}

The rapid colorimetric method recommended by King (1948) was used. Intensity of pink colour was measured at $530 \mathrm{~nm}$ in a photoelectric colorimeter, model AE 11 (Erma, Japan). The value of diacetyl and acetyl methyl carbinol were calculated from the standard curve.

\section{Sucrose tolerance test}

To $20 \mathrm{ml}$ of fresh buffalo skim milk ( $9 \%$ SNF, $0.1 \%$ fat) in the test tubes different amounts of sucrose were added so that the concentration in the test tubes was $2,6,8,10,12,14$ and $16 \%$. The contents were sterilized in an autoclave at $121{ }^{\circ} \mathrm{C}$ for $15 \mathrm{~min}$ and after cooling inoculated with the experimental cultures at the rate of $1.0 \%$. A control sample without sucrose was also run simultaneously. The tubes containing the cultures of $C_{1}, C_{10}, D R C_{1}, L F-40$ and mix- ture of $\mathrm{C}_{10}$ and $\mathrm{DRC}_{1}$ were incubated at $30^{\circ} \mathrm{C}$ for $7 \mathrm{~h}$ while the tubes containing cultures of HST, LBW and a mixture of HST and LBW were incubated at $42{ }^{\circ} \mathrm{C}$ for $4 \mathrm{~h}$. After incubation, the contents of the tubes were tested for TA.

\section{Sensory evaluation}

The samples of Misti dahi were subjected to sensory evaluation by a panel of 7 trained judges, using a 9-point hedonic scale ("most liked", 9 points; to "most disliked", 1 point).

\section{RESULTS AND DISCUSSION}

\section{Sucrose tolerance of starter cultures}

The TA developed in the presence of varying concentrations of sucrose in skim milk by different strains of starter cultures are presented in table I. The initial TA of skim milk was $0.13 \%$. The rate of TA production decreased with an increasing level of sucrose for all the experimental cultures except for HST up to $6 \%$ level of sucrose. In mesophiles, $\mathrm{C}_{10}$ showed the maximum tolerance to sucrose in the range of $6-16 \%$ concentration. Lactic acid formation by $\mathrm{DRC}_{1}$ and $\mathrm{C}_{1}$ cultures was retarded with the progressive sucrose concentration. The inhibitory effect of higher concentrations of sucrose was more pronounced in $\mathrm{DRC}_{1}$ culture. Starter culture LF-40 showed higher tolerance to sucrose than other mesophilic cultures except $C_{10}$. The mixed culture of $\mathrm{DRC}_{1}$ and $\mathrm{C}_{10}(1: 1)$ was the least effective of the mesophilic cultures in TA production.

In the thermophilic cultures, HST produced a higher percentage of acid in the presence of sucrose up to $6 \%$ than the control. $S$ thermophilus is capable of producing lactic acid from sucrose (Deibel and Seeley, 1974). Beyond the $8 \%$ level the 
Table 1. Activity of starter cultures in skimmed milk in presence of sucrose. Figures represent the means of 3 trials.

Activité des levains dans du lait écrémé en présence de sucrose.

\begin{tabular}{|c|c|c|c|c|c|c|c|}
\hline $\begin{array}{l}\text { Sucrose } \\
\text { concentration } \\
\text { (\%) }\end{array}$ & $L F-40$ & $D R C_{1}$ & $c_{10}$ & $\begin{array}{l}\text { Types of culture } \\
C_{1} \quad D R C_{1}: C_{10}(1: 1)\end{array}$ & HST & LBW & HST:LBW(1:1) \\
\hline
\end{tabular}

\begin{tabular}{ccccccccc}
\hline & \multicolumn{8}{c}{ Percent lactic acid } \\
Control & 0.55 & 0.48 & 0.43 & 0.41 & 0.40 & 0.56 & 0.39 & 0.91 \\
2 & 0.53 & 0.48 & 0.40 & 0.40 & 0.40 & 0.57 & 0.36 & 0.89 \\
4 & 0.53 & 0.46 & 0.40 & 0.38 & 0.39 & 0.59 & 0.34 & 0.89 \\
6 & 0.51 & 0.44 & 0.41 & 0.38 & 0.37 & 0.59 & 0.31 & 0.88 \\
8 & 0.50 & 0.40 & 0.40 & 0.37 & 0.37 & 0.56 & 0.28 & 0.85 \\
10 & 0.48 & 0.39 & 0.39 & 0.35 & 0.38 & 0.55 & 0.25 & 0.81 \\
12 & 0.48 & 0.37 & 0.38 & 0.34 & 0.31 & 0.54 & 0.21 & 0.78 \\
14 & 0.44 & 0.33 & 0.38 & 0.32 & 0.31 & 0.49 & 0.18 & 0.76 \\
16 & 0.41 & 0.30 & 0.37 & 0.31 & 0.29 & 0.46 & 0.16 & 0.73 \\
\hline
\end{tabular}

rate of acid production by HST gradually decreased. L bulgaricus (LBW) produced maximum acid in the control samples, but activity was severely inhibited with an increasing level of sucrose in skim milk. It has been clearly demonstrated that $S$ thermophilus has a greater tolerance to sucrose than L bulgaricus (Ray and Srinivasan, 1972; Tramer, 1973). Lactic acid production proceeded more rapidly with mixed cultures (1:1) of HST and LBW than those used singly. The symbiotic relationship of HST and LBW was clearly observed in the control samples. Their activity was not significantly affected up to $6 \%$ sucrose concentration. However, with further increase in sucrose concentration, the acid production declined, possibly due to the inhibition of Lactobacillus organisms (Tramer, 1973).

\section{Performance of starter culture in pro- duction of Misti dahi}

The initial acidity and $\mathrm{pH}$ of mix at the time of inoculation were not affected by the types of cultures used (tables II, III). The
TA and $\mathrm{pH}$ at curd setting stage were significantly influenced by the type of organism. In mesophilic cultures, LF-40 and $C_{10}$ were found to produce more acidity than the other cultures (table II). DRC 1 produced more acid than $\mathrm{C} 1$ (table III). The low TA with mixed starter culture (DRC and $\mathrm{C}_{10}$ ) may be attributed to the nonsymbiotic nature of the 2 cultures, as suggested by Patel et al (1983). On the other hand, thermophilic culture showed rather interesting results. Culture HST produced acid at a faster rate than the LBW culture (table III) as the former retains its activity even at a higher sucrose concentration of 10-12\% (Marshall and Mabbitt, 1980).

The activity of the Lactobacillus cultures was greatly affected with the increase in sucrose concentration which alters morphology by elongating and distorting the cells (Tramer, 1973). However, the mixed culture of HST and LBW showed excellent performance in terms of the highest level of acid production in the presence of sucrose. However, this combination was not found suitable for flavor production in Misti dahi. 
Table II. Effect of different cultures on physico-chemical and sensory properties of Misti dahi. Figures in parentheses are the means of 3 trials. Inoculation rate : $1.0 \%$ for all cultures.

Effet des différentes cultures sur les propriétés physico-chimiques et sensorielles du Misti dahi.

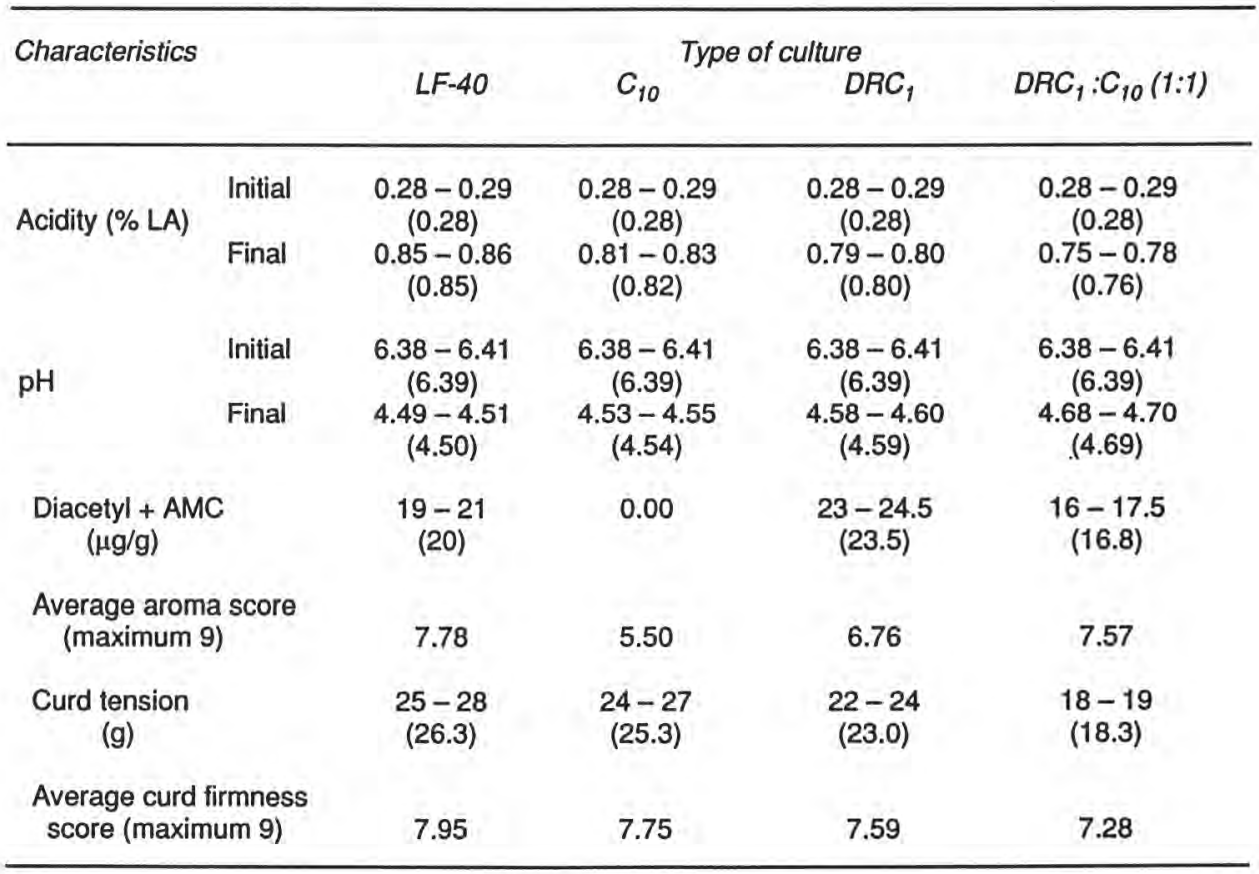

The production of flavor volatiles was found to be affected by the type of microorganism. $\mathrm{DRC}_{1}$ produced the highest amount of flavor volatiles followed by LF40 and a mixed culture of $\mathrm{DRC}_{1}$ and $\mathrm{C}_{10}$. The $\mathrm{C}_{10}$ failed to produce diacetyl and $A M C$ even after $7 \mathrm{~h}$ of incubation at $30^{\circ} \mathrm{C}$. The $\mathrm{C}_{10}$ culture is inferior to $\mathrm{C}_{1}$ from the standpoint of flavor volatile production (Dutta et al, 1971). In the thermophilic cultures, HST produced the highest amount of diacetyl and AMC (table III). S thermophilus is capable of producing flavor volatiles in milk at low concentrations (Bottazzi and Vescovo, 1969). The mixed culture produced the least amount of flavor volatiles (Bottazzi et al, 1971; Yu and Nakanishi, 1975). In our experiment, LBW culture did not perform well in flavor production in the presence of sucrose. The relative capacity of the microorganisms to ferment citrate differs considerably (Cogan, 1982). The aroma scores of Misti dahi prepared with LF-40 culture were the highest, followed by mixed culture (DRC ${ }_{1}$ and $\mathrm{C}_{10}$ ) and DRC $_{1}$ (table II). Misti dahi prepared with $\mathrm{C}_{10}$ had the lowest aroma scores. Other cultures like $\mathrm{C}_{1}, \mathrm{HST}$, LBW and mixed culture (HST and LWB) also received a very low flavor grading due to production of insufficient amounts of diacetyl and AMC. These volatiles are most important in imparting a characteristic aroma to Misti dahi. The changes in the aroma scores were found to be significant at $P<0.01$. Aroma and taste are jointly important for 
Table III. Effect of different cultures on physico-chemical and sensory properties of Misti dahi. Figures in parentheses are the means of 3 trials. Inoculation rate $=10 \%$ for all cultures. Effet des différentes cultures sur les propriétés physico-chimiques du Misti dahi.

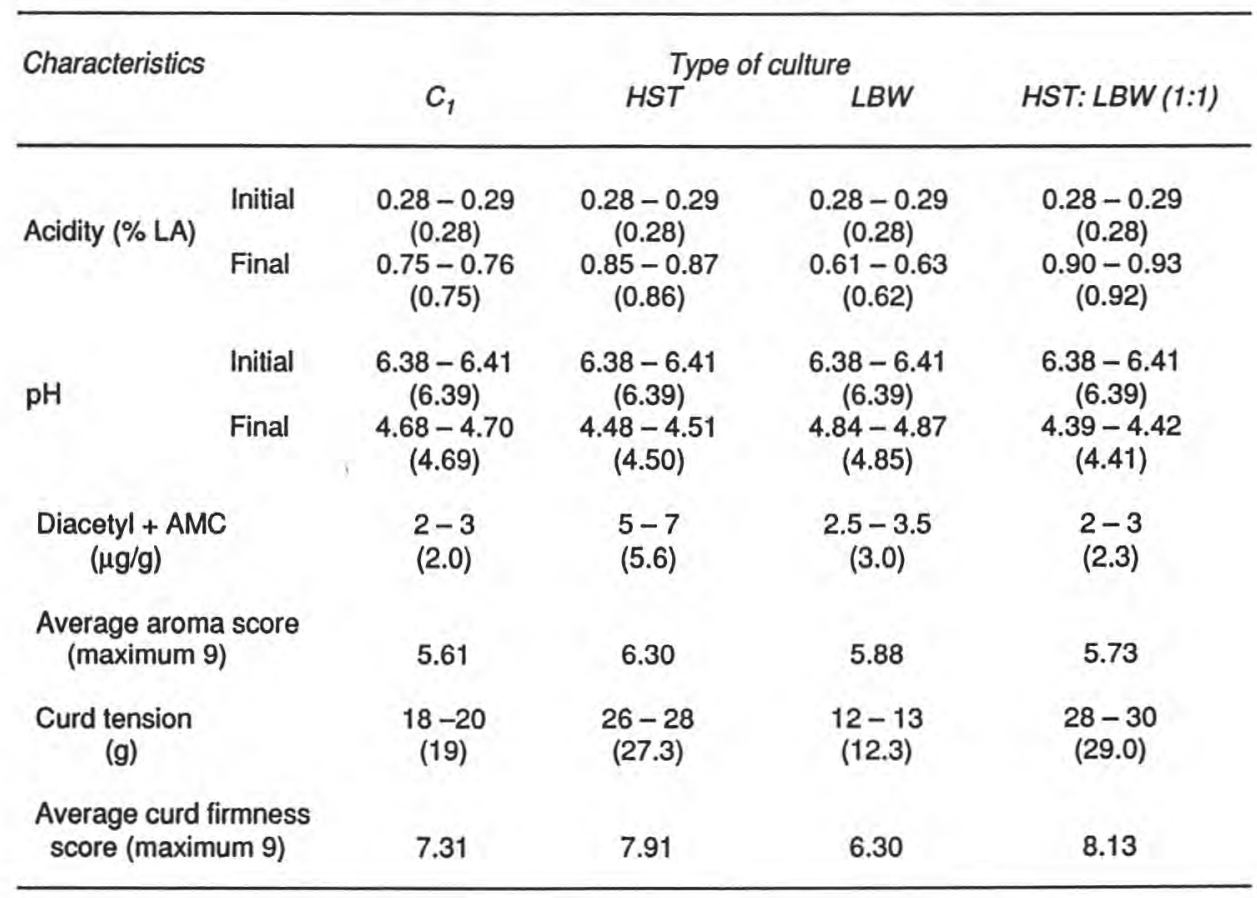

consumer acceptability of Misti dahi. In spite of the highest amount of diacetyl and AMC produced by $\mathrm{DRC}_{1}$, Misti dahi samples scored low flavor ratings because of the hetero-fermentative nature of the bacterial culture. $\mathrm{DRC}_{1}$ is known to produce small amounts of formic acid and $\mathrm{CO}_{2}$ which imparts a sharp taste to the product.

The firmness of the curd formed by the lactic culture depends on the $\mathrm{pH}$ at the time of coagulation. Gel formation is strongly supported by low $\mathrm{pH}$ in fermented milk, especially when milk receives high heat treatment leading to casein-whey protein interaction (Perry, 1974). The "most liked" curd firmness in Misti dahi was produced by mixed culture $(1: 1)$ of HST and LBW (table III) followed by LF-40 (table II) and HST. Other cultures received lower firmness ratings. The differences in the average curd firmness scores were found to be statistically significant at $P<$ 0.01 .

As the type of culture employed in the preparation of Indian fermented milk products depends upon the desired amount of acidity, flavor volatiles and optimum curd firmness, LF-40 culture proved to be most useful. Further studies were therefore conducted on LF-40 culture.

\section{Effect of inoculum levels of $L F-40$}

The flavor volatiles increased in the product with increasing percentage of inoculum, apparently as a result of higher citrate 
Table IV. Influence of LF-40 inoculum on physico-chemical and sensory properties of Misti dahi. The figures in paentheses are the means of 3 trials.

Influence de l'inoculation de LF-40 sur les propriétés physico-chimiques et sensorielles du Misti dahi.

\begin{tabular}{|c|c|c|c|c|c|}
\hline \multirow{2}{*}{\multicolumn{2}{|c|}{ Characteristics }} & \multicolumn{4}{|c|}{ Percent inoculum } \\
\hline & & 0.5 & 1.0 & 1.5 & \multirow{2}{*}{$\begin{array}{c}2.0 \\
0.28-0.29 \\
(0.28) \\
0.88-0.90 \\
(0.89)\end{array}$} \\
\hline Acidity ( $\%$ LA) & $\begin{array}{l}\text { Initial } \\
\text { Final }\end{array}$ & $\begin{array}{c}0.28-0.29 \\
(0.28) \\
0.72-0.75 \\
(0.74)\end{array}$ & $\begin{array}{c}0.28-0.29 \\
(0.28) \\
0.78-0.80 \\
(0.79)\end{array}$ & $\begin{array}{c}0.28-0.29 \\
(0.28) \\
0.80-0.84 \\
(0.82)\end{array}$ & \\
\hline $\mathrm{pH}$ & $\begin{array}{l}\text { Initial } \\
\text { Final }\end{array}$ & $\begin{array}{c}6.32-6.35 \\
(6.33) \\
4.62-4.65 \\
(4.63)\end{array}$ & $\begin{array}{c}6.32-6.35 \\
(6.33) \\
4.53-4.61 \\
(4.57)\end{array}$ & $\begin{array}{c}6.32-6.35 \\
(6.33) \\
4.49-4.56 \\
(4.53)\end{array}$ & $\begin{array}{c}6.32-6.35 \\
(6.33) \\
4.42-4.49 \\
(4.46)\end{array}$ \\
\hline $\begin{array}{c}\text { Diacetyl + AM } \\
(\mu \mathrm{g} / \mathrm{g})\end{array}$ & & $\begin{array}{c}18-19 \\
(18.6)\end{array}$ & $\begin{array}{c}20-21 \\
(20.3)\end{array}$ & $\begin{array}{c}22-25 \\
(23.3)\end{array}$ & $\begin{array}{c}25-27.5 \\
(25.7)\end{array}$ \\
\hline $\begin{array}{l}\text { Average arom } \\
\text { (maximum }\end{array}$ & score & 6.86 & 7.88 & 7.38 & 7.09 \\
\hline $\begin{array}{l}\text { Curd tension } \\
\text { (g) }\end{array}$ & & $\begin{array}{c}20-22 \\
(21.3)\end{array}$ & $\begin{array}{c}28-29 \\
(28.3)\end{array}$ & $\begin{array}{c}25-27 \\
(25.6)\end{array}$ & $\begin{array}{c}21-23 \\
(22.0)\end{array}$ \\
\hline $\begin{array}{l}\text { Average curd } \\
\text { score (maxim }\end{array}$ & $\begin{array}{l}\text { irmness } \\
\text { um 9) }\end{array}$ & 6.71 & 8.05 & 7.83 & 7.24 \\
\hline
\end{tabular}

utilization (Tiwati et al, 1972). The flavor scores were maximum in the case of samples prepared with $1.0 \%$ of inoculum. Higher doses of LF-40 inoculum produced a sharp taste, leading to low sensory ratings. The differences in flavor scores were found to be statistically significant at $P<$ 0.01 . On the basis of critical difference (0.39), 1.0 and $1.5 \%$ inoculum would give a product with almost similar quality attributes (table IV).

The firmness of Misti dahi was influenced by the percentage of inoculum. Amongst 4 dosages, $1.0 \%$ produced the best results as judged by curd tension readings. The average firmness scores were the highest in samples prepared with
$1.0 \%$ inoculum. The differences in the average scores due to amount of inoculum were significant at $P<0.01$ (table IV). Addition of $2.0 \%$ inoculum resulted in a slight weak body and coarse texture due to a high rate of acidification during incubation which might favor a very dense aggregation of protein particles with a corresponding decrease in bound water (Rasic and Kurmann, 1978).

\section{CONCLUSION}

It is concluded that LF-40 culture (mixture of various strains of $S$ lactis, $S$ diacetylactis, $S$ cremoris and Leuconostoc) is most 
appropriate for commercial production of Misti dahi from buffalo milk containing $\approx$ $18 \%$ milk solids and $14 \%$ sucrose.

\section{REFERENCES}

Bottazzi V, Battistotti B, Vescovo M (1971) Continuous production of yoghurt cultures and stimulation of Lactobacillus bulgaricus by formic acid. Milchwissenschaft 26, 214-219

Bottazzi V, Vescovo M (1969) Carbonyl compounds produced by yoghurt bacteria. Neth Milk Dairy J 23, 71-78

Chandrashekhara MR, Swaminathan M, Bhatia DS, Subramanyan V (1957) Infant food from buffalo milk. Effect of different treatments on curd tension. Food Sci Mysore 6, 226-228

Cogan TM (1982) Acetoin production and citrate metabolism in Streptococcus lactis subsp diacetylactis. Ir J Food Sci Technol 6, 69-78

Deibel RH, Seeley HW Jr (1974) Streptococcaceae fam nov. In: Bergey's Manual of Determinative Bacteriology (Buchanan RE, Gibbons NE eds) Williams and Wilkins Co, Baltimore, USA, 8th ed, 490-509

Dutta SM, Kuila RK, Ranganathan B, Laxminarayana $H$ (1971) Comparative study of the activity of starter cultures in different types of milk. Milchwissenschaft 26, 158-161

Ghosh J, Rajorhia GS (1987) Chemical, microbiological and sensory properties of Misti dahi sold in Calcutta. Asian J Dairy Res 6, 11-16

Indian Standard (1981) Dairy products, XI. In: Handbook of Food Analysis. Indian Standard Institution, New Delhi

King N (1948) A modification of the VogesProskauer test for rapid colorimetric determination of acetyl methyl carbinol plus diacetyl in the butter cultures. Dairy Ind 13, 860-861, 878

Marshall VME, Mabbitt LA (1980) The use of single starter organisms for yoghurt manufacture. J Soc Dairy Technol 33, 129-130

Parry RM Jr (1974) Milk coagulation and protein denaturation. In: Fundamentals of Dairy Chemistry (Webb $\mathrm{BH}$, Jonhson $\mathrm{AH}$, Alford JA, eds) The AVI Publishing Company Inc, Westport, 628-631

Patel AM, Dave JM, Sannabhadti SS (1983) Rate of acid production by some lactic streptococci individually and in combination in buffalo whole and skim milk at different temperatures. Gujarat Agric Univ Res J 9, 41-51

Patel RS, Chakraborty BK (1985) Reduction of curd-forming period in Shrikhand manufacturing process. Lait $65,55-64$

Rasic JL, Kurmann JA (1978) Lactic acid coagulation and factors affecting physical properties of yoghurt. In: Yoghurt-Scientific Grounds, Technology, Manufacture and Preparation, Vol I (JL Rasic, JA Kurmann eds) Technical Dairy Publishing House, Copenhagen, Denmark, 56-67

Ray HP, Srinivasan RA (1972) Use of microorganisms for production of indigenous fermented milk products (sweetened dahi) $J$ Food Sci Technol 9, 62-65

Tiwari MP, Lal M, Nambudripad VKN, Laxminara yana $H(1972)$ Studies on diacetyl production by some streptococci in milk and broth cultures. Indian J Dairy Sci 25, 263-266

.Tramer J (1973) Yoghurt cultures. J Soc Dairy Technol 26, 16-21

Yu JH, Nakanishi T (1975) Studies on production of flavour constituents by various lactic acid bacteria. V. Effect of milk fat on production of volatile carbonyl compounds by mixed lactic acid bacteria starter. Jpn J Dairy Sci 24, A117-120 